\title{
Artikkeli
}

\section{Amatöörikuvien läheisyys kriisiuutisissa toimittajien ja yleisön tulkitsemina}

\begin{abstract}
Ajatus "lähelle pääsemisestä" toistuu journalistisissa kolumneissa, juhlapuheissa ja strategiapapereissa. Läheisyydestä on tullut journalistinen strategia. Yksi uusista keinoista tuottaa journalismiin läheisyyttä on monenlaisen yleisöaineiston hyödyntäminen. Tässä artikkelissa keskitymme erityisesti kriisi- ja onnettomuusuutisissa julkaistuun kuvalliseen yleisöaineistoon, eli niin sanottuihin amatöörikuviin. Tarkastelemme amatöörikuvien läheisyyteen liittyviä merkityksiä sekä toimittajien että yleisön näkökulmasta. Näissä tulkinnoissa tulee esiin, että amatöörikuvien läheisyys perustuu etenkin niiden ajallis-tilalliseen ja tunteelliseen ulottuvuuteen. Yleisö ottaa kuitenkin toimittajia enemmän etäisyyttä siihen tapaan, jolla näitä ulottuvuuksia on koetettu uutisorganisaatioissa hyödyntää strategisesti.
\end{abstract}

AVAINSANAT: Amatöörikuvat, läheisyys, osallistuminen, toimittajat, uutisjournalismi, yleisö

Sanomalehden tärkein menestystekijä on laadukas journalistinen sisältö ja sen synnyttämä läheinen lukijasuhde. (Sanomalehtien liitto')

Y lä oleva sitaatti on Sanomalehtien liiton verkkosivuilta, jossa liitto tarjoaa koottua tietoa sanomalehtialasta. Avauslauseen mukaan lehdistön menestyvä toiminta tiivistyy kahteen tärkeään tekijään: laatuun ja läheisyyteen. Kumpikin käsite toistuu usein journalistisessa ammattipuheessa, mutta erityisesti ajatus "lähelle pääsemisestä" on viime aikoina noussut esiin kommenteissa, juhlapuheissa ja linjapapereissa. Niissä todetaan, että toimitusten pitää muodostaa läheinen yleisösuhde: jalkautua kansan pariin, ottaa vastaan palautetta, tulla osaksi yleisön arkea, tehdä koskettavia juttuja tai päästä inmisten iholle. Läheisyys on journalismissa monimerkityksinen käsite, mutta nykyään se yhä useammin tarkoittaa media- 
organisaatioiden kokonaisvaltaista yleisösuhdetta vahvistavaa strategiaa, jolla on vaikutuksensa myös journalistisiin työtapoihin ja esityksiin. Jaana Hujasen (2009, 112) mukaan suurten suomalaisten sanomalehtien toimitusjohdon käsitys 2000luvun muutosvaatimuksista kiteytyykin ajatukseen siitä, että journalismin "on tultava lähemmäksi lukijoita".

Journalismin avaaminen yleisön osallistumiselle on viime aikoina nähty yhdeksi tärkeäksi keinoksi, jolla tätä läheisyysstrategiaa voi toteuttaa (esim. Ahva 2010; Singer ym. 2011). Erilaisen yleisömateriaalin (user-generated content) käytöstä ja käyttäjien osallistamisesta on tullut keskeinen - vaikkakin journalistien ammatillisen itseymmärryksen vuoksi myös ongelmallinen - osa nykyjournalismin läheisyysajattelua (Thurman 2008; Wardle \& Williams 2008; Lewis 2012). Niin sanotut amatöörikuvat ${ }^{2}$ ovat yleisimpiä yleisömateriaalin muotoja. Erityisesti paikallis- ja ilmaisjakelumedioissa on jo jonkin aikaa julkaistu lukijoiden tai katsojien ottamia kuvia, esimerkiksi verkkoon kootuissa kuvagallerioissa (ks. Pantti \& Bakker 2009; Helle \& Lintulahti 2011; Väätäjä ym. 2012). Nykyään mediatalot käyttävät amatöörien ottamia kuvia varsin yleisesti myös uutisten yhteydessä, etenkin jos muuta kuvamateriaalia ei ole tarjolla (Wardle ym. 2014).

Aikaisemman tutkimuksen mukaan sekä journalistit että yleisö arvostavat amatöörikuvia nimenomaan niiden "lähelle tulemisen" vuoksi, millä tarkoitetaan useimmiten ajallista, fyysistä ja emotionaalista läheisyyttä (Williams ym. 2011; Puustinen \& Seppänen 2011; Andén-Papadopoulos \& Pantti 2013). Tässä artikkelissa keskitymme kriisi- ja onnettomuusuutisten yhteydessä käytettäviin "koviin" amatööriuutiskuviin, jotka ovat journalistien keskuudessa halutuimpia yleisöaineistoja (Pantti \& Bakker 2009; Allan 2014). Olemme kiinnostuneita siitä, millainen rooli läheisyydellä on näiden uutisjournalismissa hyödynnettävien amatöörikuvien osalta. Digitaalisen valokuvauksen ja erityisesti kännykkäkameroiden myötä uutistoimitukset saavat aikaisempaa nopeammin amatöörien ottamia kuvia niin kotimaisista kuin ulkomaisista tapahtumista. Kotimaassa yleisökuvien käyttö on yleistä esimerkiksi liikenneonnettomuuksia käsittelevissä uutisissa (ks. Next Media Hyperlocal 2013; Helle \& Lintulahti 2011). Ulkomaan uutisissa amatöörikuvien käyttö on tullut tavalliseksi äkillisissä luonnonkatastrofeissa ja Syyrian sodan kaltaisissa kansainvälisissä kriiseissä, joihin toimittajien on vaikea tai jopa mahdoton päästä paikan päälle. Tällöin "kansalaisjournalistien" ottamien kuvien ja videoiden merkitys korostuu uutistapahtumia läheltä kuvaavana "raakana" todistusaineistona (Allan 2013; Andén-Papadopoulos \& Pantti 2013; Peters 2001).

Tavoitteenamme on selvittää, miten kriisiuutisissa käytettävät amatöörikuvat asettuvat osaksi journalismin läheisyysstrategiaa, ja erityisesti, miten toimittajien ja yleisön näkemykset amatöörikuvien "lähentävästä" vaikutuksesta kohtaavat. Tarkastellessamme amatöörikuvia osana journalismin laajempaa läheisyysstrategiaa osallistumme samalla keskusteluun siitä, miten journalismin yleisösuhdetta vahvistetaan osallistumismahdollisuuksien kautta (esim. Picone ym. 2015; Loosen \& Schmidt 2012). Lisäksi artikkelimme täydentää mediasta ja katastrofeista tehtyä tekstien tutkimusta analysoimalla yleisön kokemuksia ja näkemyksiä amatöörikuvien potentiaalista 
tuoda vastaanottajat lähemmäksi uutisissa esitettyjä tapahtumia ja kärsiviä ihmisiä (ks. "tavallisten" inmisten äänistä kriisiuutisissa esim. Chouliaraki 2010; 2012a; Allan 2014; Andén-Papadopoulos 2014; Andén-Papadopoulos \& Pantti 2011).

\section{Läheisyyskäsitteen matka journalismin työtavasta strategiaksi}

Jotta voisimme ymmärtää, miten amatöörikuvat kiinnittyvät journalismin läheisyysstrategiaan, selvitämme ensin, mihin kaikkeen läheisyydellä (proximity) on journalismin tutkimuksen perinteessä viitattu. Käsittelemme seuraavassa käsitteen matkan työtavasta ja valintakriteeristä esitystavaksi ja lopulta strategiseksi yleisösuhdetta koskevaksi tavoitteeksi.

Läheisyyttä on pitkään tutkittu journalistisen työn tutkimuksen perinteessä, jossa siihen viitataan toimituksellisena työtapana. Tällöin läheisyydessä on kyse toimittajan ja uutisen kohteen välisestä suhteesta. Läheisyys on tarkoittanut sitä, että uutistyön tekeminen vaatii fyysistä ja ajallista läheisyyttä toimittajan ja uutiskohteen välillä: uutisorganisaatioiden ja journalistien pitää mieluiten päästä itse paikalle ja suoraan kontaktiin oleellisten lähteiden kanssa. Esimerkiksi Gaye Tuchman (1978) osoitti jo 70-luvulla, kuinka amerikkalaiset uutisorganisaatiot rakensivat tiedonhakujärjestelmänsä verkostomaisiksi niin, että tietyt fyysiset paikat - kunnantalo, poliisiasema, eduskunta - olivat uutistyön verkon keskeisiä solmuja, joita valvottiin tiiviisti niin ajallisesti kuin fyysisestikin. Tapahtumapaikoille pääsyn näkökulmasta jopa kysymys toimitusrakennusten fyysisestä sijainnista on ollut oleellinen (Gans 1970, 124). Barbie Zelizerin (1990) mukaan journalismin auktoriteetti onkin perinteisesti kummunnut siitä, että toimittajat raportoivat siitä, mitä he itse näkevät. Samasta syystä myös läheisyyteen perustuvat työtavat ovat olennainen osa journalistista auktoriteettia.

Työtapoihin liittyvien kysymysten lisäksi läheisyys on journalismin tutkimuksessa saanut merkityksen uutiskriteerinä. Kun läheisyyttä käsitellään uutiskriteerinä, puhutaan silloin uutistapahtuman tai -aiheen ja uutisen vastaanottajan välisestä suhteesta. Koska journalisti ei voi koskaan kunnolla tietää yleisöään, perustuvat kriteerit ennen kaikkea oletuksille siitä, mitä vastaanottajat pitävät tärkeänä ja kiinnostavana (Golding \& Elliot 1979). Journalismin tutkimuksessa läheisyyttä on käsitelty näihin yleisöoletuksiin liittyvänä määreenä, jonka avulla uutistoimituksissa päätetään "mitä otetaan mukaan, mitä jätetään pois ja miksi" (O’Neill \& Harcup 2008, 162). Yksinkertaistaen: jos aihe on yleisölle jollain tapaa läheinen (yleisimmin maantieteellisesti ja kulttuurisesti mutta myös emotionaalisesti, ks. Golding \& Elliot 1979, 119; Galtung \& Ruge 1965; 66-67; Schultz 2005) se nähdään toimituksissa julkaisukelpoisemmaksi kuin jokin muu aihe. Uutiskriteerit voi toki nähdä paitsi valintaperusteeksi myös legitimaatiostrategiaksi, jonka avulla journalismissa perustellaan tehtyjä valintoja (Golding \& Elliot 1979, 114; Schultz 2007, 198). Joka tapauksessa läheisyys on säilynyt uutiskriteerinä esimerkiksi journalismin oppikirjoissa, vaikka mediamaisema on muuttunut painetusta ja analogisesta digitaaliseksi ja mobiiliksi (Sheridan Burns 2002, 51-52). 
Läheisyys on tutkimuksessa saanut myös kolmannen merkityksen, sillä sitä on käytetty yhä useammin viittamaan esityksellisiin keinoihin. Tämä liittyy journalismin tutkimuksessa tapahtuneeseen kielelliseen käänteeseen, jonka jälkeen tarkasteluissa on korostunut ymmärrys uutisesta representaationa. Tästä näkökulmasta läheisyys siis koskee toimittajien suhdetta uutisteksteihin, ja tutkimuskohteena ovat tekstuaaliset keinot, joilla esityksissä "rakennetaan yleisön ja tapahtumien välille läheisyyden ja tuttuuden tunne" (Clausen 2003, 47). Ensinnäkin, koska paikalla oleminen ei aina ole mahdollista (vrt. läheisyys työtapana), tuotetaan paikan tuntu - eli ajallinen ja tilallinen läheisyys - uutisjuttuihin visuaalisten ja verbaalisten esityskeinojen avulla (Zelizer 1990, 40). Lisäksi läheisyydellä on tässä tutkimuskontekstissa selkeä emotionaalinen ulottuvuus. Journalistien käytettävissä on kasapäin kerrontaan liittyviä työkaluja, joilla tunteellista puhuttelevuutta tai koskettavuutta ja intiimiyttä voidaan rakentaa uutistekstiin. Keinovalikoimaan kuuluu esimerkiksi "tavallisen ihmisen" näkökulma (vrt. Hjarvard 2000, 69-73). Läheisyyteen liittyvät esityskeinot ovat samalla virittäneet mediaeettisen keskustelun siitä, voiko uutisjournalismi - ja pitäisikö sen - tuottaa ihmisille kokemus siitä, että he pääsisivät myös moraalisesti tai symbolisesti lähelle kriisiuutisissa kuvattuja tapahtumia ja vieraita "toisia", jolloin myös ymmärrys ja auttamishalu voisivat kasvaa (Silverstone 2003; Chouliaraki 2012b; Cottle 2013).

Aivan viime vuosikymmeninä läheisyyden käsitteen merkitys journalismin tutkimuksessa on edelleen laventunut. Kehitys heijastaa journalismissa itsessään tapahtunutta muutosta, jossa läheisyydestä on tullut uutisorganisaatioiden menestyksen tärkeä tukijalka, kuten alun sitaatista käy ilmi. Aikaisemmin ajatus läheisyydestä auttoi jäsentämään journalismin työ- ja esitystapoja sekä erittelemään uutisvalinnan kysymyksiä. Nykyään läheisyys on pikemminkin strategia, joka määrittää koko uutisorganisaation suhdetta yleisöön, ja tätä ajattelutapaa on pyritty analysoimaan ja purkamaan myös tutkimuksessa. Esimerkiksi Stig Hjarvard (2000) on kuvannut journalismin läheisyysstrategiaa Tanskassa 9o-luvun taitteessa, jolloin kansallisen yleisöradioyhtiön monopoli purettiin. Tällöin uusi kanava TV2 valtasi tilaa ja alkoi menestyä uutiskilpailussa. Hjarvardin analyysin mukaan menestys pohjautui koko organisaation läpileikkaavalle ja tietoiselle periaatteelle läheisyydestä. Tämä strategia ohjasi kanavan uutistoimintaa niin aihevalintojen kuin esitystapojenkin kautta, ja se sai sisällöissä populistis-viihteellisiä muotoja.

Tällainen muutos on tuttua Suomessakin. Jaana Hujanen (2009) puhuu "ihmisläheisestä" journalismista, joka kuvaa useissa suomalaisissa sanomalehdissä omaksuttua lähestymistapaa 2000-luvun taitteessa. Hujanen jakaa tämän läheisyysstrategian yhtäältä yhteiskunnalliseen (keskustelevaan ja palvelevaan) linjaan ja toisaalta markkinalähtöiseen (elämykselliseen ja viihteelliseen) linjaan (vrt. myös Brants \& de Haan 2010). Strateginen tavoite "lähelle pääsemisestä" on näkynyt esimerkiksi yhteiskunnallista linjaa edustavassa kansalaisjournalismin perinteessä, jossa yleisö ymmärretään kansalaisiksi ja jossa alleviivataan journalistien tiiviimpää yhteistyötä heidän kanssaan (Ahva 2010). Markkinaehtoinen läheisyysstrategia sen sijaan korostaa tarvetta luoda yhteyttä yleisöön kuluttajina, ei niinkään kansalaisina (Brants \& de Haan 2010, 417). 
Kuvio 1. Läheisyyden käsite journalismin tutkimuksessa

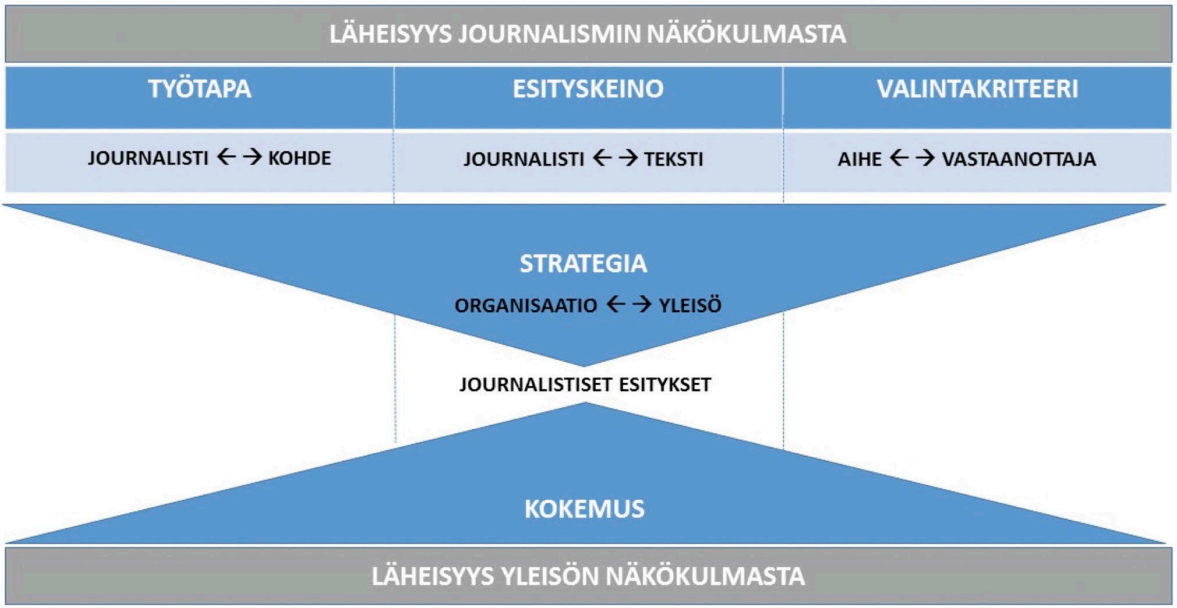

Kaikkiaan strateginen ajattelu ikään kuin kokoaa yhteen kaikki edelliset läheisyyden näkökulmat - työtavat, valintakriteerit sekä esityskeinot (ks. kuvio 1). Tällä yhdistelmällä journalistiset organisaatiot tavoittelevat läheisen yleisösuhteen rakentamista. Tämän vuoksi läheisyyteen pureutuvan journalismin tutkimuksen kannattaa liikkua koko organisaation tasolla, esimerkiksi toimituksen "me-puheessa", jota erittelemällä voi päästä jäljille siitä, miten "lähelle pääseminen" on otettu osaksi uutisorganisaation itseymmärrystä ja toimintaperiaatteita. Lisäksi tutkimuksen on tarpeen ottaa huomioon yleisön näkökulma ja pohtia, miten journalismia seuraava yleisö kokee esityksiin ladatun ja niihin kiteytyneen läheisyyden tavoitteen.

Tällaiseen strategiseen käsitykseen läheisyydestä myös amatöörikuvat sijoittuvat. Seuraavaksi tarkastelemme, mitkä näkökulmat läheisyydestä aktivoituvat, kun tulkitaan amatööriuutiskuvien käyttöä suomalaisissa uutismedioissa niin toimitusten kuin yleisönkin näkökulmasta.

\section{Aineisto ja menetelmät}

Lähdemme liikkeelle toimitusten näkökulmasta. Selvitämme, millainen on amatöörikuvien ja journalistisen läheisyysstrategian välinen kytkös suomalaisten toimittajien tulkitsemana. Vastaamme kysymykseen analysoimalla suomalaisten journalistien ja kuvatoimittajien (8 haastateltavaa) ja esimiesten (11) tulkintoja amatöörikuvista uutisissa. Aineisto koostuu kaikkiaan 19 yksittäisestä haastattelusta, jotka toteutettiin $^{3}$ yksilöhaastatteluina 2011-2012 keskeisissä suomalaisissa uutistoimituksissa (Yle, $\mathrm{MTV}_{3}$, Nelonen, Helsingin Sanomat, Aamulehti, Ilta-Sanomat, Iltalehti). Haastateltavat valittiin mukaan amatöörikuvien käytöstä olevan kokoemuksensa perusteella (käytännön uutistyö tai organisaatiotason kehittämistyö). Koska tutkimuksen fokuksessa 
on kriisijournalismi, mukaan valikoitui enemmän ulkomaan kuin kotimaan osastojen väkeä. Puolistrukturoidut teemahaastattelut kestivät puolesta tunnista tuntiin, ja niiden avulla pystyttiin kartoittamaan myös konkreettisia uutistapahtumia, joissa amatöörikuvalla oli toimittajien mukaan keskeinen rooli.

Toinen aineistomme koostuu yleisöhaastatteluista. Tämän aineiston avulla pyrimme puolestaan vastaamaan kysymykseen siitä, miten yleisö tähän strategiaan suhtautuu. Tuottaako uutisissa käytetty amatöörikuvasto yleisössä läheisyyden kokemusta ja jos tuottaa, niin miten ja missä suhteessa? Yleisöaineisto koostuu yhdeksästä ryhmähaastattelusta, joihin osallistui kaikkiaan 41 ihmistä (4-5 osallistujaa/ryhmä). Ryhmähaastattelut toteutimme Tampereen yliopiston tiloissa vuonna 2012. Haastatteluun haluttiin mahdollisimman monipuolinen ja -ääninen osallistujakunta: ryhmät valikoitiin kolmesta eri ikäryhmästä (18-34; 35-55 ja 56+), joista koottiin haastatteluihin miesten ja naisten ryhmiä sekä sekaryhmiä. Lisäksi ryhmät koottiin toisilleen entuudestaan tutuista ihmisistä. Käytännössä sovelsimme rekrytoinnissa niin sanottua lumipallomenetelmää, jossa yhteyshenkilöä pyydetään kutsumaan mukaan tai suosittelemaan omasta elämänpiiristään haastateltavia. Puolistrukturoidut teemahaastattelut kestivät 1,5-2 tuntia.

Tutkimustilanteessa näytimme yleisöryhmille kuvastoa sanomalehti-, verkko-, ja televisiouutisten yhteydessä julkaistuista jutuista. Aluksi näytimme viisi ammattikuvaajien ottamaa valokuvaa, ja tämän jälkeen amatöörikuvaajien ottamia kuvia samoista kriisi- ja onnettomuustilanteista (ks. esimerkkiparina kuvat 1 ja 2 Libyan kansannoususta; muut kuva-aiheet olivat Syyrian kapinalliset, Japanin tsunami, myrskytuhot EteläSuomessa, yökerhopalo Tampereella).

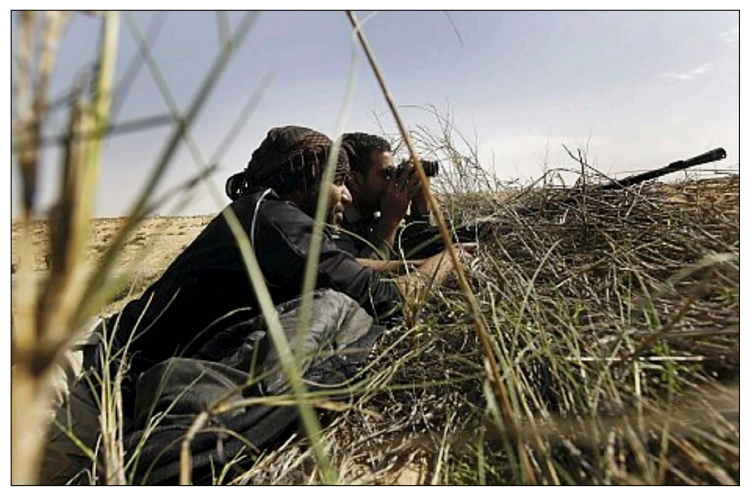

Kuva 1. "Kapinalliset olivat asemissa taistelussa Gaddafia kannattavia joukkoja vastaan Bregan kaupungissa Itä-Libyassa." (Helsingin Sanomien verkkosivut, 2.3.2011)

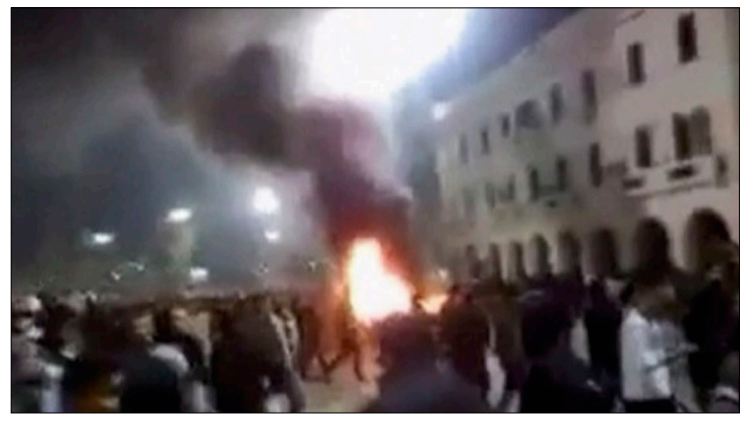

Kuva 2. "Amatöörikuvaajan videossa sanotaan näkyvän Gaddafia vastustavia mielenosoittajia kerääntyneenä pääkaupunki Tripolin kaduille 22. helmikuuta sekä useita heidän sytyttämiään tulipaloja." (Ylen verkkosivut, 24.2.2011) 
Haastattelun ytimen muodosti kuitenkin audiovisuaalisista uutisnäytteistä keskusteleminen. Näiden näytteiden aiheet (Gaddafin kiinniotto, Syyrian sota, liikenneonnettomuudet) valitsimme ryhmähaastatteluihin, koska ne nousivat esille kiinnostavina ja ristiriitaisina kohteina toimittajahaastatteluissa. Kaikille ryhmille näytimme siis seuraavat uutiset, joissa amatöörikuvastoa oli hyödynnetty hiukan eri tavoin:

1) Pääosin ammattilaiskuvaa, vain vähän amatöörikuvaa: Ylen tv-uutinen Libyasta 21.10.2011 Gaddafin kiinnioton jälkeen, "Oliko Gaddafin kuolema teloitus vai vahinko?" (2:17).

2) Pelkkää amatöörikuvaa: Nelosen verkkouutisten video ja siihen liittyvä teksti 21.10.2011 Gaddafin kiinniotosta, "Kuin pedot saaliin kimpussa: video Gaddafin löytymisestä on rumaa katsottavaa" (1:57).

3) Pääosin amatöörikuvaa, vain vähän ammattilaiskuvaa: Ylen tv-uutinen Syyriasta 23.4.2011, "Hautajaisvieraita tulitettiin Syyriassa" (2:04).

4) Pelkkää amatöörikuvaa: IL-TV:n verkkovideo ja siihen liittyvä teksti 3.2.2012 (2:21), "Hurja kolari tallentui videolle Lahdenväylällä".

Kumpikin haastattelukokonaisuus litteroitiin ensin sanatarkkaan puhekieliseen muotoonsa. Sitten analysoimme koko aineiston laadullisen sisällönanalyysin menetelmin, eli järjestimme sen ensin aiemmasta tutkimuskirjallisuudesta nousseiden teemojen mukaan. Tämän jälkeen ryhmittelimme teemoja edelleen pienempiin merkitysluokkiin ja yhdistelimme niitä aineistolähtöisesti uusien relevanttien teemojen muodostamiseksi. Tässä artikkelissa keskitymme haastatteluaineiston niihin osiin, joissa journalistit ja yleisöryhmän jäsenet tulkitsivat amatöörikuvien läheisyyttä ja sen eri ulottuvuuksia.

Aineostokokonaisuus on yhtenäinen siinä mielessä, että toimittajat ja yleisö ovat fokusoidusti saman aiheen äärellä. Tutkimustuloksia arvioidessa tulee kuitenkin ottaa huomioon ainakin kaksi rajoittavaa tekijää. Ensinnäkin toimittajat pohtivat yleisökuvien käyttöä yksilöhaastatteluissa ja yleisö ryhmätilanteissa. Päätimme kuitenkin valikoida toimittajahaastatteluiden menetelmäksi yksilöhaastattelut, koska ne mahdollistavat omakohtaisen reflektion ilman organisaatioiden hierarkia-asetelmia. Ryhmähaastattelut valitsimme yleisöosuuden menetelmäksi, koska yleisökuvien käyttö oli haastatteluiden tekemisen aikaan vielä varsin tuore ilmiö ja halusimme hakea käsittelemiseen yhteistä sanastoa ja rohkaisua eli hyödyntää ryhmien sosiaalista dynamiikkaa. Lisäksi ryhmävuorovaikutuksen on todettu tuovan yksilöhaastatteluita paremmin esille keskeisiä merkitysneuvotteluja ja -ristiriitoja (Bloor ym. 2011). Toiseksi aineistokokonaisuuksia erottaa toisistaan se, että toimittajahaastatteluissa ei katsottu esimerkkikuvia, vaan niissä liikuttiin yleisemmällä tasolla. Yleisöryhmät taas rakentuivat kuvaston varaan. Ratkaisuun päädyttiin, koska yleisöllä ei ole vakituista näkymää journalistiseen työprosessiin eli jutuntekotapoihin, aiheiden valintaan ja esitysten koostamiseen, vaan sen välitön kosketuspinta journalismiin on esitykset: tässä tapauksessa kuvat (vrt. kuvio 1). On silti huomattava, että yleisö- ja toimittajahaastattelut eivät ole keskenään vertailukelpoisia, vaan ne tuovat oman näkökulmansa läheisyyden teemaan. 


\section{Toimittajat: amatöörikuvien aika, tila ja tunne yhdistyvät strategiaksi}

Tarkastelemme seuraavassa, mitä elementtejä läheisyydestä aktivoituu toimittajien puhuessa amatöörikuvista ja miten nämä tulkintarepertuaarit kytkeytyvät läheisyyden strategiseen merkitykseen. Toimittajien puheessa korostuu vahvimmin amatöörikuvien kautta syntyvä ajallis-tilallinen läheisyys eli "paikan päällä olemisen" välittäminen. Toiseksi nousee esiin käsitys tunteellisesta läheisyydestä, joka artikuloituu "tavallisten" ihmisten ottamien kuvien synnyttämänä samastumisen potentiaalina sekä - hiukan ongelmallisesti - näiden kuvien sensaatiomaisuutena. Organisaatiotason strategisen "me-puheen" rekisterissä nämä amatöörikuvien läheisyyttä korostavat ominaisuudet valjastetaan etenkin mediabrändin palvelukseen ja osallistumisen kannustamiseen.

Amatöörikuvien avulla journalismi siis ensinnäkin näyttää pitävän yllä ajalliseen ja tilalliseen läheisyyteen kiinnittyviä työtapoja. Jos toimittajat eivät itse pääse tai ehdi tapahtumapaikalle, amatöörikuvaajat voivat paikata heidän poissaoloaan ja siten vankentaa myös journalismin auktoriteettia (vrt. Zelizer 1990). Syyrian kansannousu mainittiin haastatteluissa esimerkkinä kriisistä, jossa amatöörikuvien käyttö oli täysin perusteltua, koska journalistien pääsy maahan oli rajoitettua ja tiedot vähäisiä. Syyriasta tulevien amatöörikuvien kautta voitiin todistaa, että kriisi ylipäätään on totta: "joku on ollut paikalla, ja se on ikuistunut se hetki siihen kameraan", kuten eräs esimies kuvaa.

Koska amatöörikuvaajat ovat siellä missä tapahtuu vaikka toimittajat eivät olisikaan, toimittajien puheessa amatöörikuva rinnastetaan vahvasti silminnäkijyyteen. Amatöörikuvien käytössä silminnäkijyys on vain siirretty toimittajilta kamerapuhelimia mukanaan kantaville inmisille (Zelizer 2007). On kuitenkin tärkeää huomata, että yleisesti ottaen toimittajat edelleen korostavat omaa rooliaan merkittävien uutistapahtumien todistajina. Toimittajien läsnäolo ja omin silmin näkeminen toimivat yhä kriisijournalismin keskeisinä toimintatapoina, sillä aineistossamme toistuu ajatus siitä, että ammattilaiskuva menee useimmiten amatöörikuvan edelle. Se, että amatöörikuvien silminnäkijyys ajoittain menee ammattilaiskuvien ohi, juontuu amatöörikuvien dokumentaarisuudesta ja autenttisuudesta (ks. myös Andén-Papdopoulos \& Pantti 2013). Kuvissa on toimittajien mukaan läsnäolon ja aitouden tuntu (vrt. Pantti \& Bakker 2009). Tämä käy selvästi ilmi esimerkiksi seuraavasta televisiouutisten ulkomaantoimittajan kommentista, jossa oikeaan aikaan ja oikeassa paikassa olevan silminnäkijän koetaan tuovan tapahtumat lähemmäs katsojaa:

Just sen ajankohtaisuuden ja silminnäkijän, ikään kun sen tavallisen ihmisen näkökulma siihen uutiseen tulee huomattavasti vahvemmaksi tätä kautta, se on varmasti suurin. Päästään lähemmäksi ihmistä, se on meille ollut aina tosi tärkeä asia, mutta kyllä tämä tuo uuden väylän siihen ihan suoraan, että päästään näyttään se ihan katsojien itsensä silmin, se tietty tapahtuma. (toimittaja, televisio) 
Yllä oleva sitaatti on samalla esimerkki myös siitä, kuinka ajallis-tilallinen läheisyys kietoutuu yhteen tunteellisen läheisyyden kanssa. Toimittajat kokevat, että kuvat voivat antaa lukijalle tai katsojalle mahdollisuuden nähdä tilanteen kuin omin silmin: amatöörikuvasto voi tuottaa uutiseen tarttumapintaa tarjoamalla samastumisen kokemusta. Toimittajien tulkinnoissa amatöörikuvien avulla rakennettu tunteellinen läheisyys liittyy näkökulman vaihtamisen lisäksi vahvasti amatöörikuvien estetiikkaan. Amatöörikuvien rakeisuus ja heiluvuus näyttävät sisältävän lupauksen läheisestä ja aidosta suhteesta kuvattuun tapahtumaan (ks. myös Pantti 2013), ja siksi tämä tekninen huonolaatuisuus ollaan valmiita hyväksymään myös toimituksissa. Ulkomaantoimittaja arvioi "lähelle menevää kuvamateriaalia" seuraavasti:

Silloin ehkä se saattaa olla se tapahtuma jota ne kuvaa, saattaa olla aivan itsestään syntynyt ja aito, sillä kännykkäkameralla pääsee niin paljon lähemmäs. Et se saattaa olla se materiaali pikkasen huonompaa, mutta koska me nykyihmiset ollaan niin tottuneita tämmöiseen, ehkä pikkasen internet-tasoiseen videomateriaaliin, niin silloin me hyväksytään se, että se kuvan arvo on tärkeämpi kuin se miltä se näyttää. (toimittaja, televisio)

Etenkin kansainvälisestä kuvamateriaalista puhuttaessa toimittajat uskovat amatöörikuvien emotionaaliseen potentiaaliin kuroa umpeen etäisyys "meidän" ja fyysisesti kaukana olevien "muiden" inmisten väliltä: amatöörikuviin ja -kuvaajiin samastumalla uutistapahtumat toisella puolen maapalloa voivat tuntua yleisöstä ymmärrettäviltä ja läheisiltä. Kuvasto voi tarjota arjen tasolle menevät "surun kasvot", kuten eräs toimittaja arveli.

Läheisyyspotentiaalista huolimatta amatöörikuvat tuovat journalistien työhön myös ongelmia. Jotta esimerkiksi kuvien emotionaalista läheisyyttä voidaan hyödyntää, tulee journalistien tehdä suuri työ kuvien luotettavuuden arvioimisessa, autenttisuuden verifioimisessa ja sensitiivisyyden pohdinnassa. Toimittajat siis huomauttavat, että amatöörikuvat ovat joskus tunnetasolla liian läheisiä ja intensiivisiä. Etenkin ulkomainen kuva-aineisto voi olla hyvin raakaa: kuvataan väkivaltaisia tilanteita, ruumiita ja kauhuja ilman ammattietiikan suodattimia. Tällöin journalistien tehtäväksi tulee pitää huoli riittävän etäisyyden (vrt. Silverstone 2003) säilyttämisestä eli arvioida eettisin periaattein, mitä milloinkin voidaan julkaista ja millaisin keinoin amatöörimateriaalia upotetaan uutiskerrontaan niin, että kuvasto ei ylitä katsojien oletettua sietokykyä. Jos samasta raa'asta uutistilanteesta on tarjolla sekä amatöörien että ammattilaisten aineistoa, valitaan julkaistavaksi ammattikuvaajan otokset (vrt. Pantti 2013; Wardle ym. 2014), sillä etenkin ulkomaan tapahtumat vaativat sellaista tarkkuutta ja kontekstointitaitoa, jota amatöörikuvaajilta ei aina voi odottaa.

Amatöörikuvien läheisyys uutisvalinnan kysymyksenä ei korostunut aineistossamme, vaikka joskus pelkkä amatöörikuvien olemassaolo voikin ylittää julkaisukynnyksen (esim. iranilaisen Neda Soltanin kuolema, ks. Pantti \& Andén-Papadopoulos 2011). Toimittajahaastattelujen mukaan amatöörikuvien läheisyys perustuu siis 
etenkin siihen, että niiden avulla voidaan täydentää läheisyyteen perustuvia journalistisia työtapoja sekä saada emotionaalista puhuttelevuutta uutisen esityskeinoihin, vaikka tässä on riskinsäkin.

Kun näistä amatöörikuvien ominaisuuksista puhutaan organisaation tasolla ("mepuhe"), käy ilmi, että kuvat nähdään osana keinorepertuaaria, jolla mediaorganisaatio halutaan tuoda lähemmäs yleisöä hyvin markkinalähtöisessä mielessä. Tavoite artikuloituu aineistossa hyvin selvästi erityisesti esimiesten puheessa, jossa osallistumiseen kannustava yhteiskunnallisuus kietoutuu tiiviiksi osaksi markkinatavoitteita. Esimerkiksi metafora norsunluutornista laskeutumisesta tulee esille useassa haastattelussa. Yleisökuvien avulla halutaan astua alas tornista, vahvistaa mediatalojen mainetta ja rakentaa läheisyysbrändiä:

Siis se minkä se [amatöörikuvan käyttö] onnistuessaan tekee, niin se vie meitä lähemmäs niitä loppukäyttäjiä tai asiakkaita. Onnistuessaan se parantaa meidän brändiä ihan älyttömästi, koska meidät koetaan pikkasen arroganteiksi ja norsunluutornissa olevaksi. (esimies, televisio)

Amatöörikuviin liitettävä läheisyysstrategia toimii kaikkiaan kolmen portaan logiikalla. Ensinnäkin amatöörikuvien ajatellaan olevan esityksinä läheisen tuntuisia estetiikkansa vuoksi ja siksi houkuttelevia sisältöinä. Tällaisia uutismaisia kuvia kaivataan toimituksiin entistä enemmän. Toiseksi näiden sisältöjen toivotaan kannustavan yleisöä osallistumaan journalistiseen työprosessiin, ja tällä tavoitellaan yleisön ja mediaorganisaation vuorovaikutusta. Eräs esimies puhuu "positiivisesta osallistuttamisesta": amatöörikuvaajan identiteetti halutaan tuoda esityksissä selvästi ilmi, sillä sen koetaan osoittavan, että kaikki voivat osallistua uutistentekoon. Kolmas taso on selkeästi taloudellinen. Yksinkertaisimmillaan amatöörikuvan nähdään tuottavan lisää klikkauksia. Esimerkiksi sanomalehden toimittaja puhuu osallistumisen virittämästä "yhteenkuuluvuudesta", jonka kautta lehti myös "yrittää varmistaa tietysti markkinoita". Taloudellisesti tiukat ajat kehystävät selvästi strategiapuhetta, joka on täynnä vertailuasetelmia. Kun yleisöosallistumisesta puhutaan strategiarekisterissä, toimitusten edustajat alkavat arvioida omia organisaatioitaan suhteessa muihin medioihin. Siinä missä kaupallisen television tuottaja nostaa organisaationsa vertailukohdaksi iltapäivälehdet, iltapäivälehden toimituspäällikkö puolestaan arvioi omaa organisaatiotaan suhteessa johtaviin päivälehtiin.

Vaikka strategiapuhe korostuu esimiesten haastatteluissa, myös toimittajat ovat omaksuneet ajatustavan, jossa amatöörikuvien lupaus läheisyydestä liitetään kuvia ja työtapoja laajempiin päämääriin. Toimittajien mukaan amatöörikuvat ovat kaiken kaikkiaan "palvelua", jolla on rinnakkain sekä taloudellinen että yhteiskunnallinen merkitys, eikä tämä päällekkäisyys tuota toimittajille ristiriitaa. Eroa on kuitenkin kiinnostavasti siinä, että heidän mukaansa kotimainen kuvasto linkittyy ulkomaista vahvemmin markkinaehtoisuuteen. Kotimaiset kuvaajat nimittäin ovat myös osa kohdeyleisöä, jota halutaan sitouttaa organisaatioon. Sen sijaan kansainvälisestä kuvamateriaalista puhuttaessa rekisteri on selvästi yhteiskunnallisempi: kansalais- 
kuvaajien avulla voidaan kertoa maailman tapahtumista puolia, jotka muuten jäisivät pimentoon.

\section{Yleisö: amatöörikuvat tulevat lähelle, mutta niiden strateginen käyttötapa ei}

Analyysimme yleisöhaastatteluista osoittaa, että yleisö on yllättävissä määrin yhtä mieltä toimittajien kanssa amatöörikuvien ajallis-tilallisesta läheisyydestä sekä tunteellisen läheisyyden mahdollisuuksista ja riskeistä. Toimittajien ja yleisön tulkintojen välille muodostuu kuitenkin selkeä ristiriita amatöörikuvien strategisesta roolista.

Yleisöryhmien mukaan amatöörikuvat tuottavat läheisyyttä etenkin kuvien ottamisen ajalliseen hetkeen. Haastatteluissa kuvattiin muun muassa sitä, kuinka amatöörikuvassa "tilanne oli päällä" (mies, 18-35 v.), tai kuva on otettu "sillä hetkellä kun se tapahtuu" (mies, 36-56 v.). Ryhmähaastattelussa osallistujat usein vaihtoivat imperfektistä preesensmuotoon tulkitessaan kokemustaan kuvaushetkestä. Ajalliseen läheisyyteen liittyvät myös arviot kuvaston spontaaniudesta, satunnaisuudesta ja kiireen tunteesta: haasteltavat mieltävät kuvaajien sattuneen paikalle "akuuttihetkellä" (mies, yli 56 v.). Tämän vuoksi haastateltavat ajoittain kuvasivat tilanteita aivan kuin itse olisivat nähneet ne.

Myös tilallisen läheisyyden kokemus on vahva. Haasteltavien mukaan amatöörikuvaaja on usein fyysisesti lähellä kohteitaan, jolloin kohteena olevat inmiset ovat "ihan siinä vieressä" (nainen, 18-35 v.). Videomateriaali välittää katsojille myös ääniä, kuten huutoja, hengitystä tai laukaisuja, jolloin tilallinen läheisyyden kokemus rakentuu myös auditiivisesti. Amatöörikuvasto "havahduttaa" ja aiheuttaa yleisössä fyysisiä reaktioita, esimerkiksi saa sykkeen nousemaan tai tuottaa huimausta. Joskus valkokuvienkin katsomiskokemus on niin fyysinen, että sitä kuvataan hajuaistilla:

Tässä on vähän niin kun savun haju, ku tätä kuvaa kattoo [valokuva Libyan mellakoista, ks. kuva 2]. - - Tässä mulle tulee tunne, että tää on äkkiä, kädet vapisten kato otettu joku, että siel on tositilanne. (mies, yli 56 v.)

Ajallis-tilallisen läheisyyden kokemukset puolestaan rakentavat vahvaa pohjaa tunteelliselle läheisyydelle: yleisöryhmien jäsenet kuvasivat amatöörikuvia ennen kaikkea vaikuttaviksi ("herättävä", "tunteisiin vetoava") ja henkilökohtaisiksi ("inhimillinen", "ihmisläheinen"). Alla oleva sitaatti tiivistää, kuinka amatöörikuvat koskettavat, sillä ne tulkitaan vastakohdaksi kliiniselle (vrt. Williams ym. 2011) uutiskuvalle:

Ei tätä kauheen välinpitämättömänä voinu kattoo, tota Gaddafi-videota, edelleenkään vaikka on sen monta kertaa nähny. Kun monastihan uutiset voi ohittaa sillee että, no tämmöstä on maailmalla tapahtunu ja kauheesti tapettu, mut ne on monasti sitä vaan, aika semmosta normaalia kliinistä tavaraa. Et harvoin se menee noin lähelle, että menee vähän niin kun iholle ja tommonen. (mies, 36-56 v.) 
Haastattelujen mukaan kriisiuutisten yhteydessä julkaistuissa amatöörikuvastossa näkyy muun muassa hätä, tuska, huoli, hämmennys, raivo ja hysteria. Amatöörikuvat välittävät siis hyvin selvästi kuvaajien ja kohteiden emootioita etenkin silloin, kun kuvaaja näyttää olevan itsekin osallinen: "on kuvattu varmaan siltä miltä tuntuu" (mies, yli 56 v.). Tämän vuoksi kuvat saavat aikaan tulkitsijoissa itsessään vahvoja tunnekokemuksia. Amatöörikuvat saattavat jopa aiheuttaa "tunneryöpyn" (nainen, 36-65 v.). Haastatteluissa mainittiin ainakin pelko, huoli, järkytys ja lohduttomuus.

Vaikka toimittajat toivoivat amatöörikuvien tuottavan tunteellista läheisyyttä samastumisen ja myötätunnon kautta, yleisöhaastattelujen perusteella reaktiot olivat melko laimeita. Kuvat kyllä herättivät tunteita, mutta ne eivät alkuhämmennyksen tai tunneryöpyn jälkeen näyttäneet kehittyvän esimerkiksi auttamishaluksi. Silloin kun empaattista samastumista esiintyi, se tuli esille etenkin suhteessa tilanteisiin ja kuvaushetkiin (vrt. ajallis-tilallinen läheisyys) - ei niinkään kuvaajiin tai kuvien kohteina olleisiin ihmisiin. Kotimaisen ja ulkomaisen kuvaston välillä on tässä tapauksessa selkeä ero. Suomalaisiin tilanteisiin on helpompi samastua kuin maantieteellisesti ja kulttuurisesti kaukaisiin uutistapahtumiin. Etenkin kansainväliset uutiskuvat näyttävät ajoittain jopa vahvistavan stereotypioita "just näistä arabimaista" (mies, yli 56 v.) (ks. myös Ahva \& Hellman 2015). Esimerkiksi amatöörivideoissa kuultavat vieraskieliset huudot tuottivat haastattelutilanteissa epämääräisen ja sekasortoisen olon, jonka purkamiseksi tarvittaisiin journalistista taustoitusta, kuten seuraavasta lainauksesta käy ilmi:

Niin suomalainen ymmärtää hyvin tämmöstä suomalaisen äänenpainoo ja - - pystyy kuuntelee tunnetiloja puheesta, toisin kuin noista säheltämishuudoista [ulkomaisissa amatöörivideoissa], niin niist ei oikein ymmärrä, et onks ne ilosia, vihasia vai surullisia, vai hiljasia vai kovaäänisiä. (mies, 18-35 v.)

Haastatteluissa esiin piirtynyt tunneskaala oli kaikkiaan melko negatiivinen paljolti siksi, että tarkasteltavana olivat vakavat kriisi- ja onnettomuuskuvat. Tuntemusten negatiivinen sävy viitaa samalla siihen, että amatöörikuvien affektiivinen lataus ei näiden kriisien kohdalla herättänyt yleisöryhmissä pelkästään läheisyyttä, vaan myös etääntymisen kokemusta (ks. myös Ahva \& Hellman 2015). Tämä juontuu etenkin kuvien väkivaltaisesta ja arvaamattomasta luonteesta, eli samasta sensaatiomaisuudesta, josta toimittajatkin olivat huolissaan. Arvaamattomuus herättää halua vältellä kuvastoa, vaikka samaan aikaan haluttaisiin saada tietoa tapahtumista:

[M]ä en henkilökohtasesti kyllä tykkää siitä, että on jotenkin semmosta, just jotain verta ja tommosta, hirveetä hälinää ja muuta, koska kyllähän siitä tulee tosi semmonen paha olo, niin miks mulla pitäs olla paha olo siitä, että mä haluun saada sitä tietoa ja kattoo. Et siit on ehkä vähän tullu, ainakin itelle semmonen et ei välttämättä haluukaan sit kattoo, koska en mä voi tehä sille asialle mitään - -. (nainen, 18-35 v.)

Toinen syy etäisyyteen on amatöörikuvien tarkoitushakuisessa käyttötavassa (kuten verkkouutisten "katso järkyttävä video" -tyylisissä otsikoissa). Haastatteluiden perus- 
teella on myös hyvin selvää, että yleisö kaipaa amatöörikuvastoon suodatusta, käsittelyä ja tulkintaa eikä ole tyytyväinen siihen, kuinka media on tähän mennessä toiminut. Yleisön vastareaktio herää, jos kuvastolla liian selvästi houkutellaan tunnetason reaktioita tai klikkauksia. Ärsyyntymisen ja välttämisen lisäksi kuvia saatetaan tällaisissa tapauksissa tulkita mustan huumorin keinoin tai kyynisesti. Myös kuvien huono laatu voi etäännyttää ja tuottaa humoristisia tulkintoja, jos kuvasisältöjä pitää liiaksi arvailla. Esimerkiksi sumeaa valokuvaa Libyan katuprotesteista (ks. kuva 2) verrattiin vähätellen esimerkiksi kotimaiseen jääkiekon MM-juhlintaan tai "mihin tahansa juhannuskokkoon" (nainen, 36-56 v.). Kuvien rakeinen estetiikka ei siis aina tuota pelkästään autenttisuuden koemusta.

Kaikkiaan yleisön ja toimittajien tulkinnat amatöörikuvien sisältämästä ajallis-tilallisesta ja tunteellisesta läheisyydestä riskeineen menevät siis yllättävänkin yhteen. Selkein ristiriita rakentuu sen sijaan sen ympärille, miten toimittajat ja yleisö arvioivat sitä, kuinka nämä ominaisuudet on osattu valjastaa strategisesti. Yleisö kyllä tunnistaa tavan, jolla mediaorganisaatiot haluavat tulla lähemmäs yleisöään erilaisin osallistamiskeinoin. Amatöörikuvat osallistamisen keinona koetaan parhaimmillaan hyödylliseksi välineeksi, sillä niiden kautta voidaan täydentää ja rikastuttaa ammattijournalismin laatua (ks. myös Koskela 2013) tai avartaa maailmankuvaa tuomalla mukaan tavallisten ihmisten näkökulmaa. Haastateltavat asettivat kuitenkin itsensä pääosin suomalaismedioiden läheisyysstrategioiden ulkopuolelle: osallistumisesta puhuttiin anonyymin "kenen tahansa" näkökulmasta tai sitä pidettiin yhteiskunnallisella tasolla hyvänä periaatteena, mutta sitä ei käsitelty omana henkilökohtaisena kokemuksena tai mahdollisuutena.

Aiempienkin yleisötutkimusten mukaan ihmisillä on vankka halu uskoa toimittajien ammattitaitoon, journalismin eettisiin periaatteisiin ja suodattajan rooliin (vrt. Heikkilä ym. 2012, 176-180). Tässä mielessä yleisö nimenomaan haluaa, että uutisorganisaatiot pysyisivät hiukan etäällä "villistä" amatöörikentästä - ja jopa yleisöstä itsestään. Ihmiset vaikuttavat siksi varsin konservatiivisilta suhtautumisessaan amatöörikuvien strategiseen käyttöön ja vaativat ammattilaisilta kontrollia:

Ja siinäkin pitää kova kritiikki [mediassa olla] juuri, et jos amatööri lähettää jonkinnäkösen kuvan tai videon, omasta mielestään uutiskynnyksen ylittävästä, niin siinä pitäs just käyttää ammattimaista kriteeriä, että katotaan onko se oikeesti, ettei vaan sen rahan takia ja sen kohun aiheuttamisen takia. Et vähä pidettäs sitä moraalia. (mies, 36-56 v.)

Kuten yllä olevan sitaatin rahaan liittyvästä viittauksesta käy ilmi, haastatteluissa huomioitiin myös mediatalojen käymä kilpailu lukijoiden huomiosta ja organisaatioiden taloudellisesta asemasta. Klikkaukset, kohut ja myyminen nähtiin amatöörikuvien strategisen käytön motiiveiksi, mutta yleisö eritteli haastatteluissa näitä markkinaehtoisia motiiveita ja niiden ilmenemismuotoja kriittisesti: amatöörikuvien tunteellisen puhuttelevuuden käyttämistä uutisviihteenä kavahdettiin. Haastattelemamme yleisöryhmät olivat erityisen penseitä sitä kohtaan, että tällainen kilpailuasetelmasta kumpuava käyttötapa voisi parantaa mediaorganisaatioiden brändiä. Kaikkiaan ylei- 
sön kritiikki näyttää siis kohdistuvan uutisorganisaatioiden tapaan käyttää amatöörikuvastoa - ei niinkään kuvastoon itseensä.

\section{Päätelmät}

Tässä artikkelissa olemme käsitelleet sitä, kuinka ajatus journalismin läheisyydestä artikuloituu tavoissa, joilla amatöörikuvia käytetään kriisi- ja onnettomuusuutisissa. Sekä toimittajien että yleisön mukaan uutisissa käytetyt amatöörikuvat näyttävät tuovan yhteen ainakin kaksi läheisyyden näkökulmaa. Ensinnäkin toimittajat ja yleisö jakavat käsityksen amatöörikuvien ajallis-tilallisesta läheisyydestä. Toimittajille ajallis-tilallinen läheisyys juontuu tavasta, jolla amatöörikuvat toimivat jatkeena journalismin perinteisille läheisyyteen perustuville työtavoille, kuten silminnäkijyydelle. Samalla nämä työtavat tuottavat yleisölle esityksiä, jotka tuottavat heissä läheisyyden kokemuksen suhteessa kuvattuun tapahtumahetkeen. Journalistit ja yleisön jäsenet siis tulkitsevat samansuuntaisesti amatöörikuvien läheisyyttä suhteessa uutisten aikaan ja paikkaan: ne tuovat ajankohtaiset uutistapahtumat nopeasti lähelle kaukaakin ja tuottavat vahvan kokemuksen "paikan päällä" olemisesta. Siten kriisi- ja onnettomuusjournalismiin liittyvä kuvallinen yleisömateriaali tukee ja vahvistaa journalismin perustyötä nopean ja oleellisen tiedon välittäjänä. Tämä voi olla yksi selitys sille, miksi juuri tämä journalismin osa-alue on omaksunut amatöörikuvien käytön.

Toinen jaettu tulkinta amatöörikuvien läheisyydestä nojaa niiden emotionaaliseen potentiaaliin. Kriisi- ja onnettomuusjournalismissa käytettyjen amatöörikuvien kohdalla tunteellinen läheisyys ei kuitenkaan toimi yhtä suoraviivaisesti uutisten auktoriteetin jatkajana ja rakentajana kuin niiden ajallis-tilallinen läheisyys. Tunteellinen läheisyys on nimittäin sekä toimittajille että yleisölle enemmän esittämiseen kuin työtapoihin liittyvä kysymys, ja siten se on myös yksittäisiin esityksiin liittyvä tulkintakysymys. Toimittajat arvelevat ja toivovat, että amatöörikuvien estetiikka tuottaisi samastumisen kokoemusta, mutta yleisön näkökulmasta kukin kuva arvioidaan aina tapauskohtaisesti. Siis vaikka vahvat tunneperäiset kokemukset tulevat selvästi ilmi yleisötulkinnoissa, nämä tulkinnat eivät tuota pelkästään empatiaa tai ymmärrystä, vaan saattavat myös ruokkia stereotypioita. Toimitusten kannattaakin olla tietoisia niistä affektiivisista reaktioista, joita amatöörikuvat herättävät. Kriisi- ja onnettomuuskuvissa tämä tunnerekisteri on varsin negatiivisesti latautunut ja saattaa siksi milloin tahansa keikahtaa etäisyydeksi - etenkin väkivaltaisten tai muuten sensitiivisten aiheiden kohdalla. Toimittajat ja yleisö ovatkin yhtä mieltä siitä, että amatöörikuvat vaativat kontekstointia.

Amatöörikuvien käyttö uutisjournalismissa rakentuu selvästi myös strategisesti: amatöörikuvien ajallis-tilallinen ja tunteellinen läheisyys valjastetaan osaksi koko uutisorganisaation brändin rakentamista. Tässä toimitusten ja yleisön näkökulmat erkaantuvat toisistaan. Etenkin esimiesasemassa toimiville journalisteille läheisyys on nimenomaan mediakilpailussa taloudellisesti määrittyvä ja koko organisaation yleisösuhdetta kuvaava päämäärä, jolla journalismi voi menestyä ja jonka sisään yleisö- 
materiaalin käyttö sijoittuu. Yleisö tunnistaa tämän strategian, mutta ei ole valmis hyväksymään sen suoraviivaisimpia muotoja, kuten klikkausten kalastelua. Siksi etenkin markkinaehtoinen, elämyksellisyyttä korostava läheisyyslinja näyttää aiheuttavan kitkaa yleisön ja mediaorganisaatioiden välille. Yhteiskunnallisemmassa mielessä virittynyt läheisyysstrategia ei sen sijaan saa ihmisiä innostumaan henkilökohtaisesti, vaikka ajatus nähdäänkin yleisesti kannatettavana.

Journalismin auktoriteettia tukevoittavaksi tarkoitettu tavoite läheisyydestä ei siten resonoi yleisötulkintojen kanssa suoraviivaisesti, vaan yleisö käy siitä jatkuvaa merkitysneuvottelua. Siten yleisösuhteen tiivistämistä tavoittelevien mediatalojen on otettava huomioon, että erilaiset osallistamisen menetelmät liikkuvat aina ulottuvuudella, jonka toisessa päässä on mukaan pääseminen ja toisessa päässä poispäin kääntyminen. Ytimessä on kysymys siitä, miten amatöörikuvien sisältämää läheisyyspotentiaalia käytetään. Amatöörikuvien hyödyntäminen tuottaa läheisyyttä vain, jos journalismin omat läheisyystavoitteet ja yleisön odotukset läheisyydestä ovat toisiaan vastaavia (vrt. Loosen \& Schmidt 2012). Vaikka amatöörikuvat läheisyyttä korostavina esityksinä ja työtapoina näyttävätkin toimivan hyvin sekä journalismin että yleisön näkökulmasta katsottuna, ei näitä ominaisuuksia näytä olevan helppo siirtää strategian tasolle, sillä yleisö haluaa pysytellä yllättävänkin etäällä mediaorganisaatioista.

\section{Viitteet}

1 http://www.sanomalehdet.fi/sanomalehtitieto/journalismi

2 Journalistisissa organisaatioissa käytetään usein ilmauksia "lukijakuvat" tai "yleisökuvat". Kansainvälisen materiaalin sisällyttäminen tarkasteluun tuottaa kuitenkin tilanteen, jossa kuvan ottaja tai lähettäjä ei aina ole julkaisun lukija tai osa sen yleisöä, jolloin nämä määritelmät ovat liian suppeita. Käytämme siksi termiä amatöörikuva. Ymmärrämme kuitenkin, että kuvaajat eivät aina ole "amatöörimäisiä", vaan itse asiassa usein puoliammattilaisia, aktiivisia kuva-harrastajia tai taitavia media-aktivisteja. Amatöörillä viittaamme tässä ei-ammattimaisiin kuvaajiin, joiden materiaalia julkaistaan valtavirtamediassa. Haastattelijana toimi tutkija Minttu Tikka.

\section{Kirjallisuus}

Ahva, Laura (2010). Making News with Citzens: Public Journalism and Professional Reflexivity in Finnish Newspapers. Tampere: Tampere University Press.

Ahva, Laura \& Hellman, Maria (2015, tulossa). Citizen eyewitness images and audience engagement in crisis coverage. International Communication Gazette 77.

Allan, Stuart (2014). Witnessing in crisis: Photo-reportage of terror attacks in Boston and London. Media, War Q Conflict 7: 2, 133-151.

Allan, Stuart (2013). Citizen Witnessing: Revisioning Journalism in Times of Crisis. Cambridge: Polity.

Andén-Papadopoulos, Kari (2014). Citizen-camera witnessing: Embodied political dissent in the age of 'mediated mass self-communication'. New Media Q Society 16: 5, 753-769.

Andén-Papadopoulos, Kari \& Pantti, Mervi (toim.) (2011). Amateur Images and Global News, Bristol: Intellect.

Andén-Papadopoulos, Kari \& Pantti, Mervi (2013). Re-imagining crisis reporting: Professional ideology of Journalists and citizen eyewitness images. Journalism 14: 77, 960-977.

Bloor, Michael; Frankland, Jane; Thomas, Michelle \& Robson, Kate (2001). Focus Groups in Social Research. London: Sage. 
Brants, Kees \& de Haan, Yael (2010). Taking the public seriously: Three models of responsiveness in media and journalism. Media, Culture and Society 32: 1, 411-428.

Chouliaraki, Lilie (2010). Ordinary witnessing in post-television news: Towards a new moral imagination. Critical Discourse Studies 7: 4, 305-319.

Chouliaraki, Lilie (2012a). Re-mediation, inter-mediation, trans-mediation. Journalism Studies 14: 2, 267-283.

Chouliaraki, Lilie (2012b). The Ironic Spectator: Solidarity in the Age of Post-Humanitarianism. Cambridge: Polity.

Clausen, Lisbeth (2003). Global News Production. Copenhagen: CBS Press.

Cottle, Simon (2013). Journalists witnessing disaster. Journalism Studies 14: 2, 232-248.

Galtung, Johan \& Ruge, Marie (1965). The structure of foreign news: The Presentation of the Congo, Cuba and Cyprus Crises in four Norwegian newspapers. Journal of Peace Research 2: 1, 64-90.

Gans, Herbert (1979). Deciding What's News. London: Constable.

Golding, Peter \& Philip, Elliot (1979). Making the News. London: Longman.

Heikkilä, Heikki; Ahva, Laura; Siljamäki, Jaana \& Valtonen, Sanna (2012). Kelluva kiinnostavuus: Journalismin merkitys ihmisten sosiaalisissa verkostoissa. Tampere: Vastapaino.

Helle, Merja \& Lintulahti, Matti (2011). Benchmarking best practices of local hyperlocal content and business models. Next Media TIVIT Programme. Saatavilla: http://www.mediaconceptsrg.net/ wp-content/uploads/2013/02/D3.2.1.1_-D3.2-.1.4-Hyperlocal-Benchmarking-hyperlocal-contentcreation-and-business-models-Merja-Helle.pdf (luettu 27.2.2015).

Hjarvard, Stig (2000). Proximity: The name of the ratings game. Nordicom Review 21: 2, 63-81.

Hujanen, Jaana (2009). Kiinnostavaa vai tärkeää? Ihmisläheisen journalismin kaksi polkua. Teoksessa: Väliverronen, Esa (toim.). Journalismi murroksessa. Helsinki: Gaudeamus, 112-128.

Koskela, Katri (2013). Tiedon ja tunteen kuvat: Yleisötutkimus amatöörikuvien koetusta vaikutuksesta journalismin laatuun. Pro gradu. Helsingin yliopisto, valtiotieteellinen tiedekunta, viestinnän oppiaine.

Lewis, Seth C. (2012). The tension between professional control and open participation. Information, Communication Q Society 15: 6, 836-866.

Loosen, Wiebke \& Schmidt, Jan-Hinrik (2012). (Re-)discovering the audience: The relationship between journalism and audience in networked digital media. Information, Communication Q Society 15: 6, $867-887$.

Next Media Hyperlocal (2013). Tuloskooste 2013. Saatavilla: http://virtual.vtt.fi/virtual/nextmedia/ uutiskoosteet/Next_Media_hyperlocal_2013.pdf (luettu 27.2.2015).

O'Neill, Deirdre \& Harcup, Tony (2008). News values and selectivity. Teoksessa: Wahl-Jorgensen, Karin \& Hanitzsch, Thomas (toim.). The Handbook of Journalism Studies. London: Routledge, 161-175.

Pantti, Mervi (2013). Getting closer? Encounters of the national media with global citizen images. Journalism Studies 14: 2, 201-218.

Pantti, Mervi \& Andén-Papadopoulos, Kari (2011). Transparency and trustworthiness: Strategies for incorporating amateur photography into news discourse. Teoksessa: Andén-Papadopoulos, Kari \& Pantti, Mervi (toim.). Amateur Images and Global News, Bristol: Intellect, 199-112.

Pantti, Mervi \& Bakker, Piet (2009). Misfortunes, memories and sunsets: Non-professional images in Dutch news media. International Journal of Cultural Studies 12: 5, 471-481.

Peters, John Durham (2001). Witnessing. Media, Culture Q Society 23: 6, 707-723.

Picone, Ike; Courtois, Cédric \& Paulussen, Steve (2015). When news is everywhere: Understanding participation, cross-mediality and mobility in journalism from a radical user perspective. Journalism Practice 9: 1, 35-49.

Puustinen, Liina \& Seppänen, Janne (2011). In amateurs we trust: Readers assessing non-professional news photographs. Teoksessa: Andén-Papadopoulos, Kari \& Pantti, Mervi (toim.). Amateur Images and Global News, Bristol: Intellect, 175-192.

Schultz, Brad (2005). Broadcast News Producing. London: Sage.

Schultz, Ida (2007). The journalistic gut feeling: Journalistic doxa, news habitus and orthodox news values. Journalism Practice 1: 2, 190-207.

Sheridan Burns, Lynette (2002). Understanding Journalism. London: Sage.

Singer, Jane B.; Hermida, Alfred; Domingo David; Heinonen Ari; Paulussen Steve, Quandt, Thorsten, Reich Zvi \& Vujnovic Maria (2011). Participatory Journalism: Guarding Open Gates at Online Newspapers, Chichester: Wiley-Blackwell. 
Silverstone, Roger (2003). Proper distance: Towards an ethics for cyberspace. Teoksessa: Liestøl, Gunnar; Morrison, Andrew \& Rasmussen, Andrew (toim.). Digital Media Revisited: Theoretical and Conceptual Innovations in Digital Domains. Cambridge, Mass: MIT Press, 469-490.

Thurman, Neil (2008). Forums for citizen journalists? Adoption of user generated content initiatives by online news media. New Media Q Society 10: 1, 139-157.

Tuchman, Gaye (1978). Making News: A Study in the Construction of Reality. New York: Free Press.

Väätäjä, Heli; Vainio, Teija \& Sirkkunen, Esa (2012). Location-based crowdsourcing of hyperlocal news: Dimensions of participation preferences. Proceedings of the $17^{\text {th }}$ ACM International Conference, 85-94.

Wardle, Claire; Dubberley, Sam \& Brown, Pete (2014). Amateur footage: A global study of usergenerated content in TV and online news output. A Tow/Knight Report. Tow Center for Digital Journalism. Colombia School of Journalism. Saatavilla: http://towcenter.org/wp-content/ uploads/2014/04/80458_Tow-Center-Report-WEB.pdf (Iuettu 27.2.2105).

Wardle, Claire \& Williams, Andrew (2008). UGC@THEBBC: Understanding its impact upon contributors, noncontributors and BBC News. Final Report. Cardiff: Cardiff School of Journalism, Media and Cultural Studies.

Williams, Andrew; Wahl-Jorgensen, Karin \& Wardle, Claire (2011). 'More real and less packaged': Audience discourses on amateur news content and their effects on journalism practice. Teoksessa: AndénPapdopoulos, Kari \& Pantti, Mervi (toim.). Amateur Images and Global News. Bristol: Intellect, 193209.

Zelizer, Barbie (1990). Where is the author in American TV news: On the construction and presentation of proximity, authorship, and journalistic authority. Semiotica 80: 1-2, 37-48.

Zelizer, Barbie (2007). On 'having been there': 'Eyewitnessing' as a journalistic key word. Critical Studies in Media Communication 24: 5, 408-428. 